\title{
Effect of Variable-Depth Tillage System on Energy Requirements for Tillage Operation and Productivity of Desert Soil
}

\author{
Adil Abd Elsamia Meselhy \\ Agricultural Mechanization Unit, Soil and Water Conservation Department - Desert Research Center, Cairo, Egypt \\ Email address: \\ adil_meselhy@yahoo.com \\ To cite this article: \\ Adil Abd Elsamia Meselhy. Effect of Variable-Depth Tillage System on Energy Requirements for Tillage Operation and Productivity of \\ Desert Soil. International Journal of Applied Agricultural Sciences. Vol. 7, No. 1, 2021, pp. 38-49. doi: 10.11648/j.ijaas.20210701.13
}

Received: November 14, 2020; Accepted: January 5, 2021; Published: January 22, 2021

\begin{abstract}
Tillage systems classified into two groups: conventional (CT) and conservation (CVT) tillage. The first group (CT), soil inverted and crop residues buried. (CT) has some disadvantages. Firstly, disturbing the soil unnecessarily in areas where the soil structure and condition is not required is wasteful of time and fuel. Secondly, incorrect tillage depth can cause damage to the soil structure, which can lead to the formation of a compaction layer. The second group, (CVT) defined as no-tillage with leaving at least $30 \%$ of the crop residue on the field. (CVT) improves the efficient usage of the natural resources of water and soil. However, (CVT) has some drawbacks such as not recommended if the soil has compaction problems. Recently a third group emerged, namely variable-depth tillage (VDT), or precision tillage technology optimizes soil physical properties only where the tillage needed by applying tillage at the required depth. (VDT) has been shown to reduce costs, labor, fuel consumption and energy requirements. To implement (VDT) system, it is necessary to determine and map soil penetration resistance, spatially and with depth through the soil profile. Therefore, an experiment conducted in a field to evaluate a technology to determine the tillage depth based on soil penetration resistant at different depths of soil. The field experiment area divided into five plots (no-tillage uniform-depth tillage at $25 \mathrm{~cm}$ tillage depth - uniform-depth tillage at $35 \mathrm{~cm}$ tillage depth - uniform-depth tillage at $45 \mathrm{~cm}$ tillage depth - variable-depth tillage) where, no-tillage indicated to (CVT), uniform-depth tillage indicated to (CT) and (VDT) indicated to precision tillage. The study measurements were fuel consumption rate (FCR), actual field capacity (AFC), power requirements (PR), specific energy (SE), operating costs (OC), soil penetration resistance (SPR) and sorghum yield (SY). The results showed that compaction layer occurred between the soil depths of $25 \mathrm{~cm}$ and $35 \mathrm{~cm}$. Therefore, the (VDT) system was used at a tillage depth of $35 \mathrm{~cm}$. The average ratio from total field area that needed to till was about $47 \%$. The results showed that (VDT) system caused a decreasing in the (FCR), (PR) and (OC) about 35\%, 35\% and 23\%, respectively, compared to uniform-depth tillage system (UDT), while the (AFC) for VDT system increased about $21 \%$ compared to (UDT). The (SY) for (VDT) system increased about $53 \%$ compared to (UDT) at $25 \mathrm{~cm}$ tillage depth, while the (SY) for VDT system decreased about $8 \%$ and $11 \%$ compared to (UDT) at $35 \mathrm{~cm}$ and $45 \mathrm{~cm}$ tillage depth, respectively.
\end{abstract}

Keywords: Conventional Tillage, No-Tillage, Soil Compaction, Soil Penetration Resistant, Sorghum Crop Yields, Variable-Depth Tillage

\section{Introduction}

Conventional tillage system, in general, less than 15 percent residue cover left on the soil after planting [1]. Conventional tillage practices use a whole field approach in which the tillage effect is applied uniformly across the whole field. Management decisions on which tillage machinery to use and how deep to operate it at are usually decided on historical management or occasionally based on, information derived from a soil profile inspection. This universal approach is attractive to growers because it requires little specialist knowledge of the soil, simply relying on tillage machinery design to achieve a satisfactory result. On the other hand, there are several disadvantages to this approach. Firstly, from an economic perspective, disturbing the soil unnecessarily in areas where the soil structure and condition is not required is wasteful of time and fuel [2]. Secondly, 
incorrect tillage depth can cause damage to the soil structure by smearing wet plastic soil [3] which can lead to the formation of an impervious layer, restricting the development of plants roots, negatively impacting on yield. Finally, inappropriate tillage may cause the soil to be susceptible to erosion where nutrients are not retained in the soil but are lost to the environment through leaching and runoff. Conservation tillage methods used especially to preserve soil and soil water, and to create a sustainable environment. This system is of great interest as it improves the efficient use of the natural recourses: water, soil, and energy. Conservation tillage is defined as "any tillage or planting system in which at least $30 \%$ of the soil surface is covered by plant residue after planting to reduce erosion by water or wind" [1]. Conservation tillage systems have advantages for both soil and water resources. Soil conserved by eliminating erosion via crop residues and water conserved by leaving the crop residues on the soil surface so that the water under the soil surface cannot evaporate. Additional positive effects are improvement surface and ground water quality, reduced labor, time and fuel savings, decreased erosion, higher soil moisture, improved water infiltration, decreased soil compaction, more wildlife and biological activity, reduced release of carbon gases, and reduced air pollution [4]. The conservation tillage has also some disadvantages. The main drawback is its requirement of careful farm management practices. Other disadvantages can be as follows:

1. increase of soil pests populations,

2. Increase of herbicide usage to control weeds competing with the main crops,

3. Transfer of insect pests and diseases from the crop residues to the next crop,

4. Uneven distribution and concentration of organic matter in the topsoil,

5. More time required until methods result in an excellent soil quality.

Conservation tillage also not recommended if the soil has compaction problems. Soil compaction restricts the root and crop development resulting in a reduction in yield. The alternative approach to conventional tillage and conservation tillage practices is advanced tillage methods, soil tilled based on the variation on the soil conditions and properties. The aims of the advanced tillage methods are to use less fuel and energy and to prevent excessive soil disturbance by varying the tillage applications. Different terms can be used as advanced tillage methods: variable-depth tillage, site-specific tillage or precision tillage (part of Precision Agriculture, PA). Using these tillage applications, it is possible to vary the soil tillage depth according to the data from a data source, either a variability map or a real time sensor. Therefore, this method called Map-Based or Sensor-Based Site-Specific Tillage based on the data source. These methods applied for removing the compacted soil layer at variable-depth tillage [5]. Soil compaction can be naturally occurring or machinery-induced [6]. Naturally occurring soil compaction often facilitated by a soil that contains many different sizes of soil particles [7]. Machinery-induced soil compaction is due to vehicle traffic from large and heavy equipment used in agricultural fields. Many studies have shown that soil compaction increased under row middles that have been subjected to vehicle traffic, as opposed to traffic middles where no traffic has occurred [8]. Soil compaction, caused by either natural causes or human interference, is a major yield limiting factor. This is because soil compaction: 1) reduces soil pore size, 2) changes pore size distribution, 3) increases soil strength, 4) reduces air and water permeability, 5) increases heat capacity and bulk density, and most importantly, 6) increases root penetration resistance [9]. A high-energy input is required to disrupt hardpan layer to promote improved root development and increased drought tolerance. Significant savings in tillage energy could be achieved by site-specific management of soil compaction. Site-specific variable-depth tillage system can be defined as any tillage system, which modifies the physical properties of soil only where the tillage is needed for crop growth objectives. The energy cost of subsoiling decreased by as much as $34 \%$ with site-specific tillage as compared to the uniform-depth tillage technique currently employed by farmers [10]. In addition, a 50\% reduction in fuel consumption by sitespecific or precision deep tillage [11]. Tillage implement energy directly related to working depth, tool geometry, travel speed, width of the implement and soil properties [12]. Soil properties that contribute to tillage energy are moisture content, bulk density, cone index and soil texture [13]. Farmers apply uniform depth subsoiling annually to mechanically disrupt the hardpan layers and improve the root environment for optimal crop growth [14]. The application of this energy intensive uniform subsoiling based on the assumption that the compacted layers are located at a constant depth. The relative strength and depth of the hardpans, however, vary from field to field and within fields [15]. With uniform depth subsoiling, tillage may be applied in areas of the field where there is no soil compaction problem or at depths that do not necessarily correspond to the hardpan depth. This may incur unnecessary fuel consumption or the desired soil conditions may not be attained. The benefits of variable-tillage depth on crop profitability, ecology and the environment. variable- depth tillage in particular is geared towards achieving the goals of sustainable agriculture by determining within-field variability and providing more accurate records of soil compaction; and eventually reducing tillage energy and fuel consumption [16]. About 50\% reduction in energy requirements for shallow tillage (approximately $18 \mathrm{~cm}$ ) versus deep tillage (approximately $33 \mathrm{~cm}$ ) [17]. Approximately $75 \%$ of the test area required tillage operations shallower than the commonly used tillage depth. They reported energy and fuel savings of $42.8 \%$ and $28.4 \%$ respectively by adopting variabledepth tillage as compared to uniform-depth tillage [18]. The depth to a critical cone index value $(2 \mathrm{MPa})$ used as the sitespecific tillage depth. At this critical value plant root, growth is severely impeded [11]. If the soil penetration value is greater than 2-3 MPa (300-435 psi), the crop growth is limited [19]. Also determined typical value of cone index that stops root growth to be near 2.07 MPa (300 psi) [20]. An instrumented subsoiler designed to map hardpans using dynamic operation of the implement. The maps obtained could be used to prescribe variable-depth tillage in different places within a field. A control 
system such as the one developed by [18] could then be used to guide the tillage equipment to the appropriate depth. Proper adjustments to equipment, operating techniques, and implement selection can increase working efficiency leading to a decrease in fuel consumption [21]. Site-specific tillage is one modern tillage method that eliminates consuming excessive energy for unnecessary uniform-depth deep tillage and minimize disturbance of surface residue needed for erosion control [22]. Energy and fuel usage savings of $50 \%$ and $30 \%$, respectively, could be attained using variable-depth tillage. Optimum tillage depth may be deeper or shallower than what is conventionally applied making uniform-depth tillage costly. Therefore, there is a need for a technology to determine the tillage depth based on the thickness and depth of the compacted layer and apply tillage accordingly. This type of variable-depth tillage technology could be beneficial in optimizing the production costs. Since a highenergy input is required to disrupt the hardpan layer to promote improved root development, variable-depth tillage could result in significant savings in energy required for the tillage [23]. Variable-depth tillage or site-specific tillage is one of the important applications of Precision Agriculture, which based on the concept of treating small areas of the field as separate management units [24]. Farmers do not usually know if annual subsoiling is required, where it is required in a field, nor the required depth of subsoiling. Also, there is significant variability in depth and thickness of hardpan layers from field to field and also within a field. Therefore, applying uniform-depth tillage over the entire field may be either too shallow to fracture the hardpan or deeper than required resulting in excess fuel consumption [25]. Ideally both the depth and thickness of the hardpan needs to be known to accurately control a variable depth tillage system. Also, there is little to no gain from tilling deeper than required to fracture the compacted layer [26]. A soil tillage resistance sensor that was able to appropriately measure the hardpan depth and thickness to a depth of $46 \mathrm{~cm} \mathrm{[27].}$

Therefore, the objectives of this study were to developing a control system to determine the soil hardpan depth and the immediate intervention to tillage it, evaluation the control system for carried out variable-depth tillage system and quantitatively determine the effects of this system on energy requirements, and plant responses in crop production.

\section{Materials and Methods}

\subsection{Field-testing}

The experiment area was about one-hectare divided into five pieces to apply five study treatments (no-tillage - uniform-depth tillage at $25 \mathrm{~cm}$ tillage depth - uniform-depth tillage at $35 \mathrm{~cm}$ tillage depth - uniform-depth tillage at $45 \mathrm{~cm}$ tillage depth - variable-depth tillage) arranged in randomized complete blocks with three replications. Each piece divided into 5 rectangles in width and 8 rectangles in length to form a plot of $80 \times 25 \mathrm{~m}$ with an area of $2000 \mathrm{~m}^{2}$, as shown in Figure 1. Field experiment was conducted in El-Sadat City, Menoufia Governorate at latitude: $30^{\circ} 19^{\prime} 5^{\prime \prime}$ $\mathrm{N}$, longitude: $30^{\circ} 32^{\prime} 33^{\prime \prime} \mathrm{E}$, with sandy loam soil (Coarse sand $7.6 \%$, Fine sand $51.4 \%$, silt $18.4 \%$ and clay $22.6 \%$ ). The average moisture content, bulk density and penetration resistant of soil surface layers (0-25, 25-35 and 35-45) cm were determined as shown in Table 1. A complete set of cone penetrometer measurements were obtained using horizontal penetrometer by Meselhy, (2020) [28] at soil depths 25, 35 and $45 \mathrm{~cm}$ across the entire field. The depth and thickness of the hardpan were determined from the collected data using the criteria defined by Taylor and Gardener, (1963) [21]. Within each plot, it was decided to set the tillage depth that would rupture compacted layers of the soil with cone index values above 300 psi. The hardpan layer located between 25 and $35 \mathrm{~cm}$ soil depth so that the variable-depth tillage system applied at $35 \mathrm{~cm}$ tillage depth which, compared with two tillage systems conventional (uniform-depth tillage) and conservation (no-tillage). Uniform-depth tillage system (conventional tillage) carried out at $25 \mathrm{~cm}$ tillage depth (above hardpan layer), $35 \mathrm{~cm}$ tillage depth (at hardpan layer) and $45 \mathrm{~cm}$ tillage depth (below hardpan layer). No-tillage (conservation tillage) carried out by direct sowing sorghum seeds using seeder machine. All tillage treatments implemented using chisel plow five blades at forward speed $3.13 \mathrm{~km} / \mathrm{h}$ and all study treatments planted by sorghum seeds using mechanic seeder at forward speed $4.5 \mathrm{~km} / \mathrm{h}$. The sorghum crop (fresh forage) planted in April to September 2020 (one season) by a seeder machine, with a rate of $60 \mathrm{~kg} / \mathrm{ha}$ and harvested in two cuts as a fresh forage.

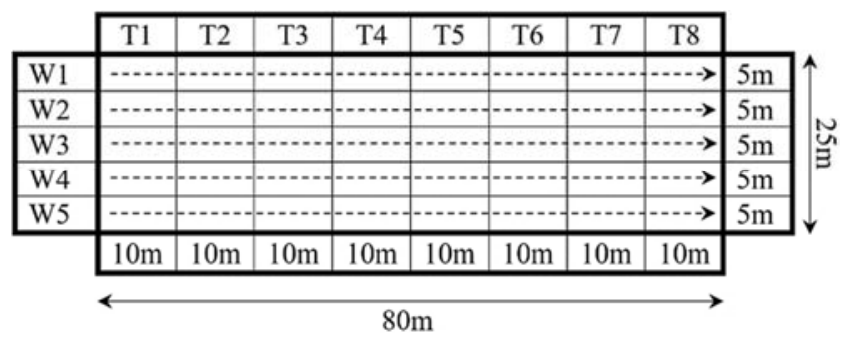

Figure 1. Each plot area $2000 \mathrm{~m}^{2}$ divided into 5 rectangles in width (25m) and 8 rectangles in length $(80 \mathrm{~m})$. Arrows indicated to movement lines of horizontal penetrometer.

Table 1. Some soil physical properties for experiment area.

\begin{tabular}{llll}
\hline Soil depth $(\mathbf{c m})$ & Average soil penetration resistance $(\mathbf{k P a})$ & Soil bulk density $\left(\mathbf{g} / \mathbf{c m}^{\mathbf{3}}\right)$ & Soil moisture content $(\mathbf{\%})$ \\
\hline $0-25$ & 878 & 1.54 & 16.44 \\
$25-35$ & 2054 & 1.79 & 10.67 \\
$35-45$ & 1861 & 1.67 & 7.49 \\
\hline
\end{tabular}




\subsection{Horizontal Penetrometer}

Horizontal penetrometer by Meselhy, (2020) [28] consisted of a tine with a multi-tips horizontal sensor using replaceable cone tips, was developed to measure the soil penetration resistance at multiple depths as shown in Figure 2 The width of tine was $20 \mathrm{~mm}$. The apex angle of both tips was 30 degrees with the same base area of $254 \mathrm{~mm}^{2}$ (The diameter of the base of the cone was $18 \mathrm{~mm}$ ) (ASAE Standard, 2004) [29]. The tips were mounted horizontally on the tine face. The sensing shafts were mounted horizontally on the tines, and their depths were 25,35 and $45 \mathrm{~cm}$ from soil surface. The sensing unit of system mounted on the backside of each shaft and contact with oscilloscope device to measuring and recording the change of output voltages by change in variable resistance. This change in variable resistance was made by the shaft, which connected between it and the cone. Each sensing unit of the instrumented tine was calibrated in the laboratory by applying known forces and measuring output voltages.

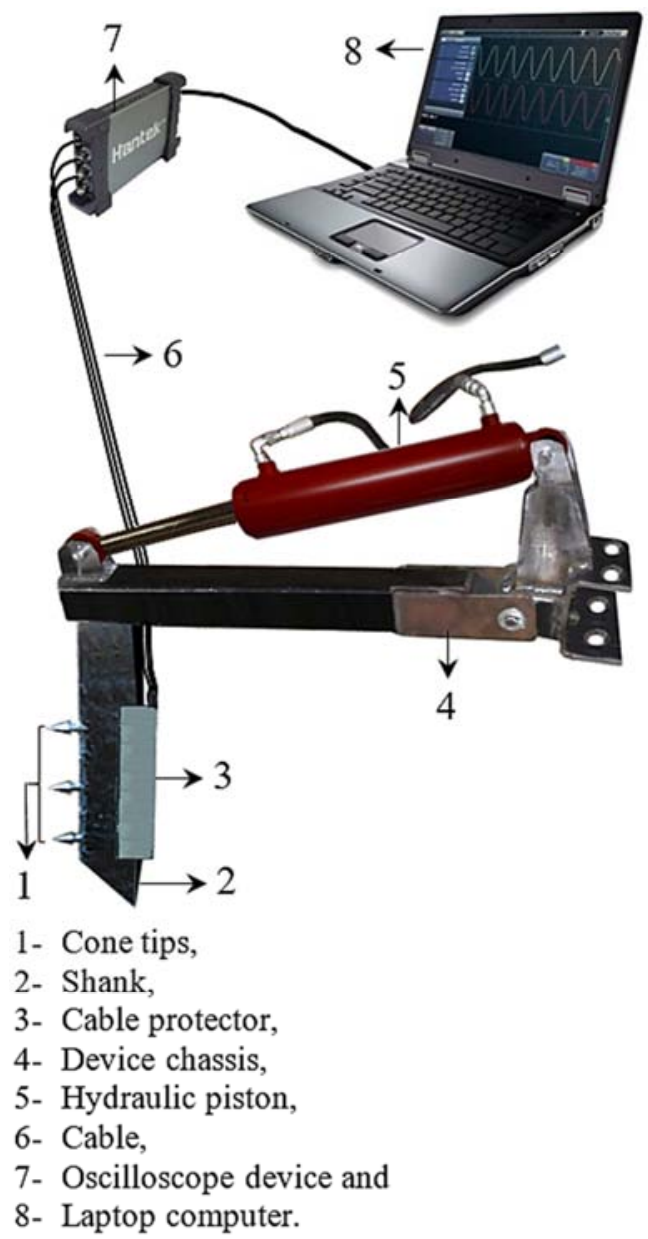

Figure 2. The horizontal penetrometer system components (HPS).

\subsection{Method of Carried out the Variable-depth Tillage System}

The variable-depth tillage system carried out by creating electrical circuit consisted of a battery, lamp and electrical disconnection switch, where one of the two ends of the switch was moving with the horizontal penetrometer cone rod and the second end of the switch fixed as shown in the Figure 3. When the cone rod of the horizontal penetrometer moves under the pressure of soil resistance, the end of the circuit switch moves with it, and as long as the soil resistance does not reach a value of $2 \mathrm{MPa}$, the switch remains open. However, if the soil resistance increased to $2 \mathrm{MPa}$, the key end of the circuit connected to the fixed end, and turns on the lamp in the control panel front of the tractor driver, which moves the plow to the required depth. If the soil resistance lower than $2 \mathrm{MPa}$, the end of the switch moves away from the fixed end, which causes opening of the circuit and turns off the lamp then the tractor driver raises the plow from the soil. The three tips of horizontal penetrometer at the three depths of the soil $(25-35-45) \mathrm{cm}$ connected to electrical circuit as previously mentioned. Therefore, the control panel front of the tractor driver contained three lamps (for three soil depths) indicating a certain depth. The horizontal penetrometer placed in front of the tractor with using suitable tractor forward speed to provide enough time for raising and lowering the plow depending on the soil resistance as shown in Figure 4 (a and b).

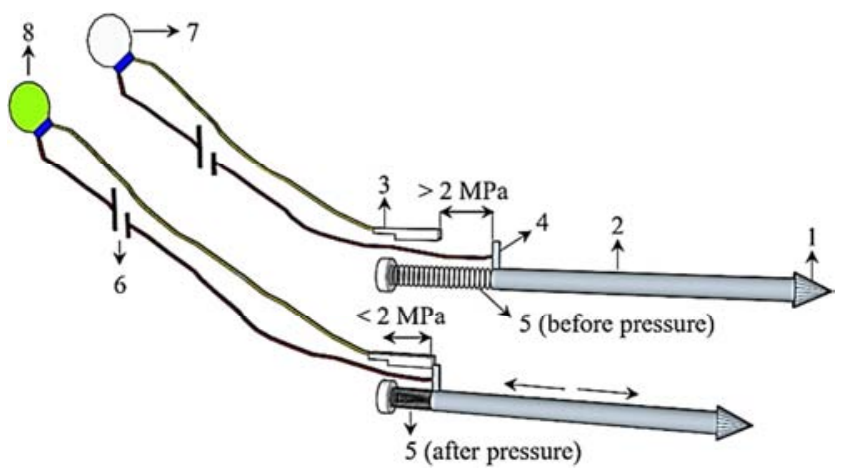

Figure 3. Mechanism of indicating soil resistance values above $2 M P a$. The items are (1) cone tip, (2) cone rod, (3) the fixed point of electrical current switch on and off, (4) the moving point of electrical current switch on and off, (5) spiral spring, (6) battery, (7) electrical lamp is shut down and (8) electrical lamp is light.

\subsection{Actual field Capacity}

Actual field capacity was calculated by using equations mentioned by kepner et al., (1978) [30].

\subsection{Fuel Consumption Rate}

Fuel consumption per unit time was determined by measuring the volume of fuel consumed during operation time. It was measured using the fuel meter equipment as shown in Figure 5. The length of line, which marked by the marker tool on the paper sheet represents the fuel consumption. The fuel meter was calibrated prior and the volume of fuel was determined accurately.

\subsection{Fuel Consumption per Unit Area}

Fuel consumption per unit area was determined by using 
the following equation:

\section{$\mathrm{FCA}=\mathrm{FCT} / \mathrm{AFC}$}

Where: $\mathrm{FCA}=$ Fuel consumption per unit area $(1 / \mathrm{ha})$, $\mathrm{FCT}=$ Fuel consumption per unit time $(\mathrm{l} / \mathrm{h})$ and $\mathrm{AFC}=$ Actual field capacity (ha/h).

(a)

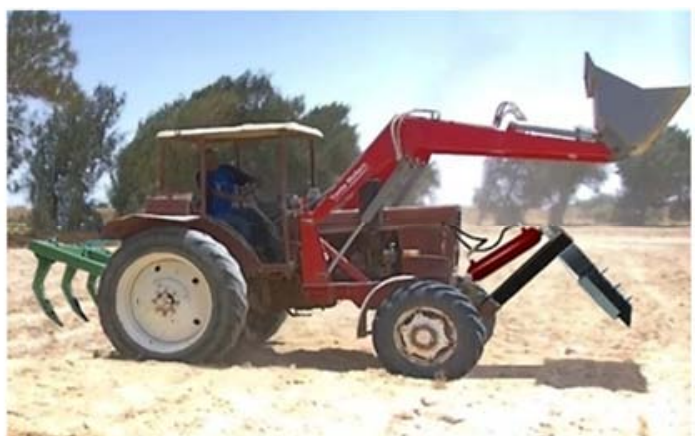

(b)

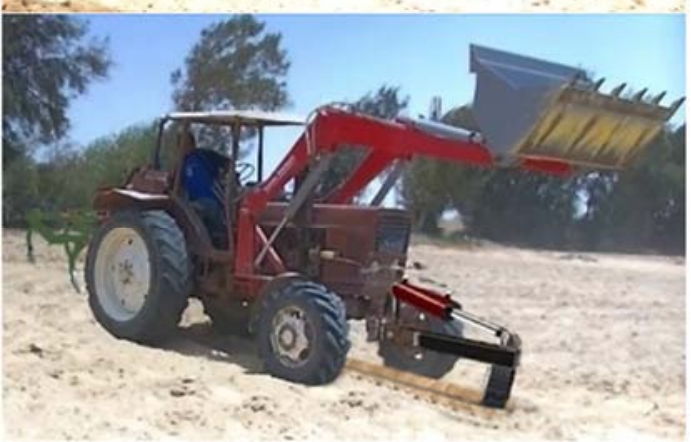

Figure 4. The horizontal penetrometer mounted on the tractor in field: a) penetrometer outside the soil and b) penetrometer inside the soil.
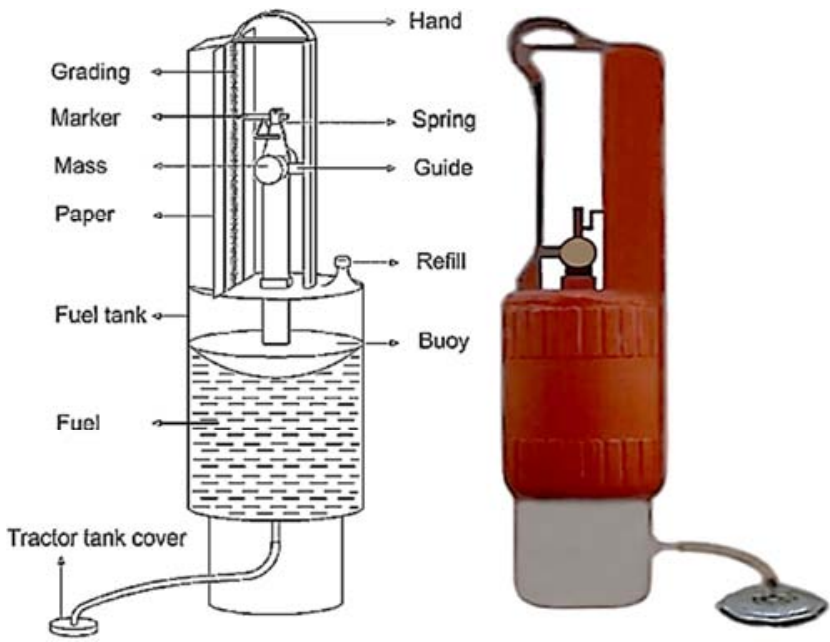

Figure 5. Fuel meter for measuring fuel consumption.

\subsection{Total Cost of Performing a Tillage Operation}

Total hourly cost was determined according to EL-Awady, (1978) [31] as follows:

$$
\begin{gathered}
\mathrm{C}=\left(\frac{\mathrm{p}}{\mathrm{h}}\right) *\left(\frac{1}{\mathrm{~L}}+\frac{\mathrm{i}}{2}+\mathrm{t}+\mathrm{r}\right)+(1.2 * \mathrm{RFC} * \mathrm{f})+\left(\frac{\mathrm{m}}{144}\right)+\left(\frac{\mathrm{P}_{1}}{\mathrm{~h}_{1}}\right) * \\
\left(\frac{1}{\mathrm{~L}_{1}}+\frac{\mathrm{i}}{2}+\mathrm{t}+\mathrm{r}_{1}\right)
\end{gathered}
$$

Where: $\mathrm{C}=$ Hourly cost $(\mathrm{LE} / \mathrm{h}), \mathrm{P}=$ Initial price of the tractor
(LE), $\mathrm{h}=$ Yearly working hours of tractor $(\mathrm{h} /$ year), $\mathrm{L}=\mathrm{Life}$ expectancy of the tractor (year), $\mathrm{t}=$ Annual taxes and overheads ratio $(\%), \mathrm{f}=$ Fuel price $(\mathrm{LE} / \mathrm{L}), \mathrm{m}=$ The monthly average wage (LE/month), 1.2=Factor accounting for lubrication, $\mathrm{RFC}=$ Actual rate of fuel consumption $(1 / \mathrm{h})$, $\mathrm{i}=$ Annual interest rate $(\%), \mathrm{r}=$ Annual repairs and maintenance ratio for tractor $(\%), \mathrm{P}_{1}=$ Initial price of the implement (LE), $\mathrm{h}_{1}=$ Yearly working hours of implement (h/year), $r_{1}=$ Annual repair and maintenance ratio for implement (\%), 144=Operation monthly average working hours (h) and $\mathrm{L}_{1}=$ Implements life expectancy (year).

\subsection{Total Cost per Unit Area}

Total cost per unit area was determined as follows:

$$
\mathrm{TCA}=\mathrm{C} / \mathrm{AFC}
$$

Where: $\quad \mathrm{TCA}=$ Total cost per unit area, (LE/ha), $\mathrm{AFC}=$ Actual field capacity, $(\mathrm{ha} / \mathrm{h})$ and $\mathrm{C}=$ Hourly cost, $(\mathrm{LE} / \mathrm{h})$.

\subsection{Power Requirements}

Power requirements were determined from fuel consumption for each operation using the following relation Hunt and Welson, (2015) [32]:

$\mathrm{PR}=\left(\mathrm{F}_{\mathrm{c}} * \frac{1}{3600}\right) * \rho_{\mathrm{f}} *$ L. C. $\mathrm{V} * 427 * \eta_{\mathrm{th}} * \eta_{\mathrm{m}} * \frac{1}{75} * \frac{1}{1.36}(4)$

Where: $\mathrm{PR}=$ Power requirements due to fuel consumption, $(\mathrm{kW}), \mathrm{F}_{\mathrm{c}}=$ Fuel consumption rate, $(\mathrm{L} / \mathrm{h}), \rho_{\mathrm{f}}=$ Density of the fuel, $(\mathrm{kg} / \mathrm{l})$ (for solar fuel $=0.85 \mathrm{~kg} / \mathrm{l})$, L.C.V $=$ Lower calorific value of fuel, $(\mathrm{kcal} / \mathrm{kg}$ ) (average L.C.V of solar fuel is 10000 $\mathrm{kcal} / \mathrm{kg}), 427=$ Thermal-Mechanical equivalent, $(\mathrm{kg} . \mathrm{m} / \mathrm{kcal})$, $\eta_{\mathrm{th}}=$ Engine thermal efficiency (assumed to be $40 \%$ for diesel engine) and $\eta_{\mathrm{m}}=$ Engine mechanical efficiency, (assumed to be $70 \%$ for diesel engine).

\subsection{Specific Energy}

The specific energy in (kw.h/ha) can be calculated as follows:

$$
\mathrm{SE}=\mathrm{PR} / \mathrm{A}_{\mathrm{f.c}}
$$

Where: $\quad$ SE=Specific energy, $\quad(\mathrm{kW} \cdot \mathrm{h} / \mathrm{ha}), \quad \mathrm{PR}=$ Power required for a particular operation, $(\mathrm{kW})$ and $\mathrm{A}_{\mathrm{f} . \mathrm{c}}=$ Actual field capacity, (ha/h).

\section{Results and Discussions}

\subsection{Distribution of Soil Penetration Resistance Before Tillage for Five Experimental Pieces at Different Soil Depths}

The soil penetration resistance was measured for the fiveareas from field experiment using the horizontal penetrometer of the soil layers $0-25 \mathrm{~cm}, 25-35 \mathrm{~cm}$ and 35 $45 \mathrm{~cm}$, and maps of the soil penetration resistance distribution were drawn as shown in Figures 6, 7, 8, 9, 10 and 11. These maps showed that the soil layers from $0-25 \mathrm{~cm}$ and $35-45 \mathrm{~cm}$ 
did not reach to the values of soil penetration resistance equal or above $2 \mathrm{MPa}$, while their values exceeded $2 \mathrm{MPa}$ with soil layer $25-35 \mathrm{~cm}$ in all five-test areas. The percentage of soil area that exceeded the value of $2 \mathrm{MPa}$ and required to tillage were $47.5 \%, 42.5 \%, 45 \%, 50 \%$ and $50 \%$ for treatments notillage, uniform-depth tillage of $25 \mathrm{~cm}$, uniform-depth tillage of $35 \mathrm{~cm}$, uniform-depth tillage of $45 \mathrm{~cm}$ and variable-depth tillage respectively as shown in Figure 7. From these results, cleared that the experiment area required plowing at a depth of $35 \mathrm{~cm}$ and at an average percentage about $47 \%$ from the entire experiment area. Therefore, variable-depth tillage performed at tillage depth of $35 \mathrm{~cm}$ and in areas where the values of soil penetration resistance exceeded $2 \mathrm{MPa}$.

\section{(a) No-Tillge}

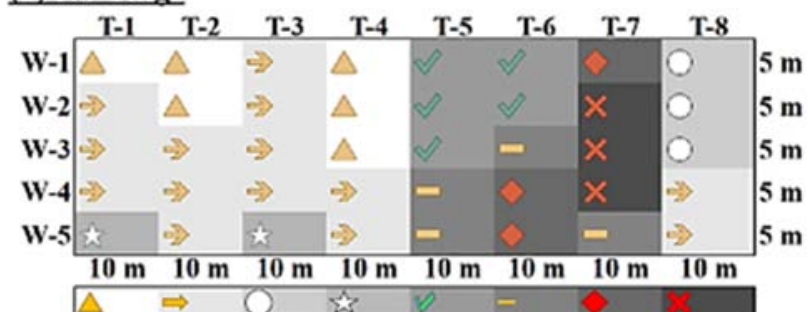

Penetration range (kPa)

\begin{tabular}{|c|c|c|c|c|c|c|c|c|}
\hline 737 & 788 & 839 & 890 & 941 & 992 & 1043 & \multirow{2}{*}{$>1093$} & Fro \\
\hline 787 & 838 & 889 & 940 & 991 & 1042 & 1093 & & \multirow{2}{*}{$\begin{array}{c}\text { To } \\
\text { Total }\end{array}$} \\
\hline er of & ch col & & & & & & & \\
\hline 6 & 14 & 3 & 2 & 5 & 4 & 3 & 3 & 40 \\
\hline feach & color ( & & & & & & & Total \\
\hline 300 & 700 & 150 & 100 & 250 & 200 & 150 & 150 & \multirow{2}{*}{2000} \\
\hline & ach $\mathrm{c}$ & lor (\% & & & & & & \\
\hline 15 & 35 & 7.5 & 5 & 12.5 & 10 & 7.5 & 7.5 & 100 \\
\hline
\end{tabular}

Table of data analysis for soil map

\section{(b) Uniform-depth tillage at $25 \mathrm{~cm}$}

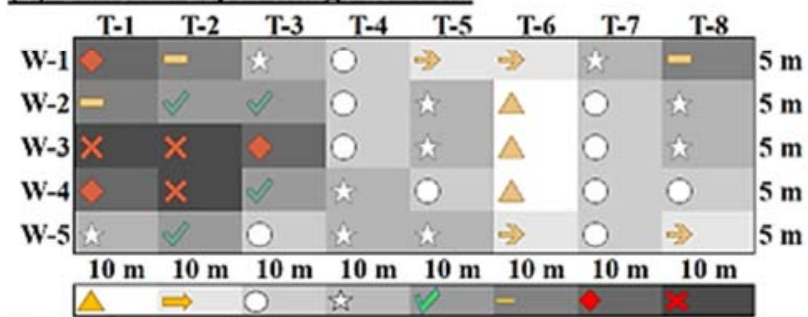

Penetration range (kPa)

\begin{tabular}{|c|c|c|c|c|c|c|c|c|}
\hline 712 & 748 & 784 & 820 & 856 & 892 & 928 & \multirow{2}{*}{$>963$} & \multirow{2}{*}{\begin{tabular}{|c|} 
From \\
To \\
\end{tabular}} \\
\hline 747 & 783 & 819 & 855 & 891 & 927 & 963 & & \\
\hline$r$ of & ch co & & & & & & & Total \\
\hline 3 & 4 & 10 & 10 & 4 & 3 & 3 & 3 & 40 \\
\hline of eacl & color & & & & & & & Total \\
\hline 150 & 200 & 500 & 500 & 200 & 150 & 150 & 150 & 2000 \\
\hline age 0 & each & lor $(\%$ & & & & & & Total \\
\hline 7.5 & 10 & 25 & 25 & 10 & 7.5 & 7.5 & 7.5 & 100 \\
\hline
\end{tabular}

Figure 6. Distribution map of soil penetration resistance $(\mathrm{kPa})$ before tillage for two experimental pieces at soil layer $0-25 \mathrm{~cm}$ : a) no-tillage and b) uniform-depth tillage at $25 \mathrm{~cm}$. Where $T$ and $W$ are the symbol of rectangle area as shown in previously Figure 1. (a) Uniform-depth tillage at $35 \mathrm{~cm}$

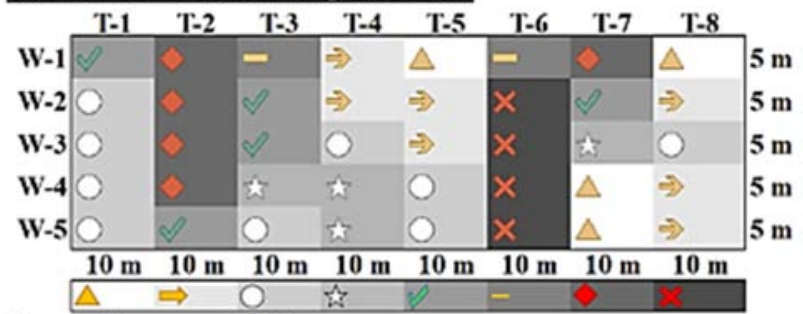

Penetration range (kPa)

\begin{tabular}{|c|c|c|c|c|c|c|c|c|}
\hline 729 & 765 & 801 & 837 & 873 & 909 & 945 & \multirow{2}{*}{$>980$} & \multirow{2}{*}{\begin{tabular}{|c|} 
From \\
$T_{0}$
\end{tabular}} \\
\hline 764 & 800 & 836 & 872 & 908 & 944 & 980 & & \\
\hline \multicolumn{8}{|c|}{ er of each color } & Total \\
\hline 4 & 7 & 9 & 4 & 5 & 2 & 5 & 4 & 40 \\
\hline \multicolumn{8}{|c|}{ of each color $\left(\mathrm{m}^{2}\right)$} & \multirow{2}{*}{$\begin{array}{l}\text { Total } \\
2000\end{array}$} \\
\hline 200 & 350 & 450 & 200 & 250 & 100 & 250 & 200 & \\
\hline age 0 & & & & & & & & \multirow{2}{*}{ Total } \\
\hline 10 & 17.5 & 22.5 & 10 & 12.5 & 5 & 12.5 & 10 & \\
\hline
\end{tabular}

Table of data analysis for soil map

(b) Uniform-denth tillage at $45 \mathrm{~cm}$

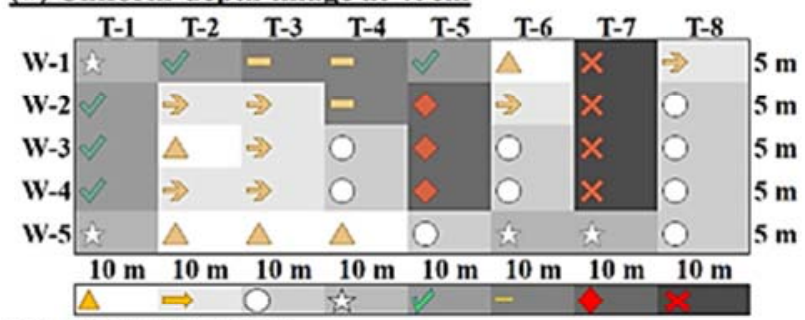

Penetration range $(\mathrm{kPa})$

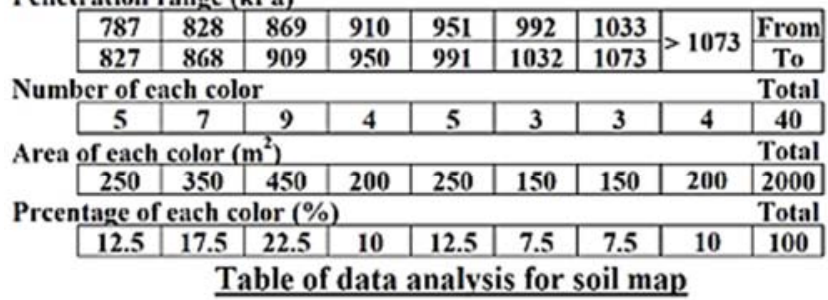

(c) Variable-depth tillage

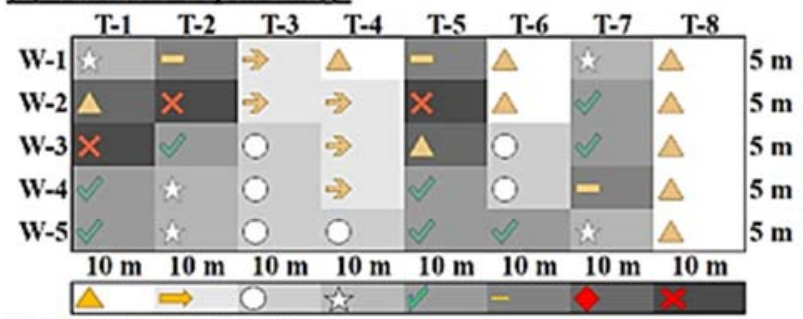

Penetration range (kPa)

\begin{tabular}{|l|l|l|l|l|l|l|l|l|}
\hline 815 & 856 & 896 & 937 & 978 & 1019 & 1060 & \multirow{2}{*}{ From } \\
\hline 855 & 895 & 936 & 977 & 1018 & 1059 & 1100 & & To \\
\hline
\end{tabular}
\begin{tabular}{|c|c|c|c|c|c|c|c|c|}
\hline 815 & 856 & 896 & 937 & 978 & 1019 & 1060 & $>1100$ & From \\
\cline { 1 - 7 } & 895 & 936 & 977 & 1018 & 1059 & 1100 & & To \\
\hline
\end{tabular}

Number of each color \begin{tabular}{|c|c|c|c|c|c|c|c|c|}
\hline 8 & 5 & 6 & 5 & 8 & 3 & 2 & 3 & 40 \\
\hline
\end{tabular}

Area of each color $\left(\mathrm{m}^{2}\right)$ \begin{tabular}{|c|c|c|c|c|c|c|c|c|}
\hline 400 & 250 & 300 & 250 & 400 & 150 & 100 & 150 & 2000 \\
\hline
\end{tabular}

Prcentage of cach color (\%) Total \begin{tabular}{|l|c|c|c|c|c|c|c|c|}
\hline 20 & 12.5 & 15 & 12.5 & 20 & 7.5 & 5 & 7.5 & 100 \\
\hline
\end{tabular} Table of data analysis for soil map

Figure 7. Distribution map of soil penetration resistance $(\mathrm{kPa})$ before tillage for three experimental pieces at soil layer $0-25 \mathrm{~cm}$ : a) uniform-depth tillage at $35 \mathrm{~cm}$, b) uniform-depth tillage at $45 \mathrm{~cm}$ and c) variable-depth tillage. Where $T$ and $W$ are the symbol of rectangle area as shown in previously Figure 1. 
(a) No-tillage

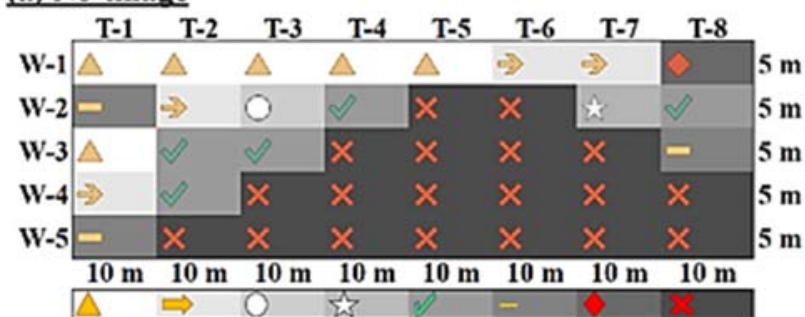

Penetration range $(\mathrm{kPa})$

\begin{tabular}{|l|l|l|l|l|l|l|l|l|}
\hline 1748 & 1785 & 1821 & 1857 & 1893 & 1929 & 1965 & & \\
\hline 1784 & 1820 & 1856 & 1892 & 1928 & 196 & 2000 & From \\
\cline { 2 - 4 } & &
\end{tabular} \begin{tabular}{|l|l|l|l|l|l|l|l|l|}
\hline 1784 & 1820 & 1856 & 1892 & 1928 & 1964 & 2000 & $>2000$ & $T_{0}$ \\
\hline
\end{tabular}

Number of each color Total \begin{tabular}{|l|l|l|l|l|l|l|l|l|}
\hline 6 & 4 & 1 & 1 & 5 & 3 & 1 & 19 & 40 \\
\hline
\end{tabular}

Area of each color $\left(\mathrm{m}^{2}\right)$ Total

\begin{tabular}{|l|l|l|l|l|l|l|l|l|}
\hline 300 & 200 & 50 & 50 & 250 & 150 & 50 & 950 & 2000 \\
\hline
\end{tabular}

Prcentage of each color (\%)

\begin{tabular}{|l|l|l|l|l|l|l|l|l|}
\hline 15 & 10 & 2.5 & 2.5 & 12.5 & 7.5 & 2.5 & 47.5 & 100 \\
\hline
\end{tabular}

Table of data analysis for soil map

(b) Uniform-depth tillage at $25 \mathrm{~cm}$

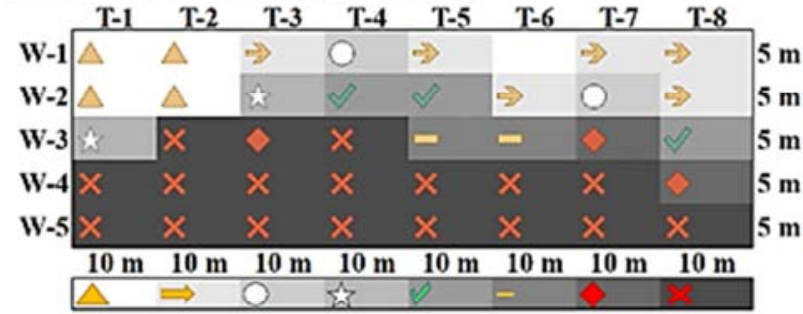

Penetration range ( $\mathrm{kPa})$

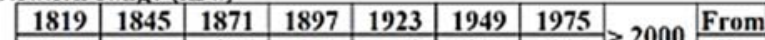

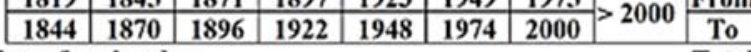
Number of each color

\begin{tabular}{|c|c|c|c|c|c|c|c|c|}
\hline 5 & 6 & 2 & 2 & 3 & 2 & 3 & 17 & 40 \\
\hline
\end{tabular}

Area of each color $\left(\mathrm{m}^{2}\right)$

\begin{tabular}{|l|l|l|l|l|l|l|l|l|}
\hline 250 & 300 & 100 & 100 & 150 & 100 & 150 & 850 & 2000 \\
\hline
\end{tabular}

Prcentage of each color (\%)

\begin{tabular}{|l|c|c|c|c|c|c|c|c|}
\hline 12.5 & 15 & 5 & 5 & 7.5 & 5 & 7.5 & 42.5 & 100 \\
\hline
\end{tabular}

Table of data analvsis for soil map

(c) Uniform-depth tillage at $35 \mathrm{~cm}$

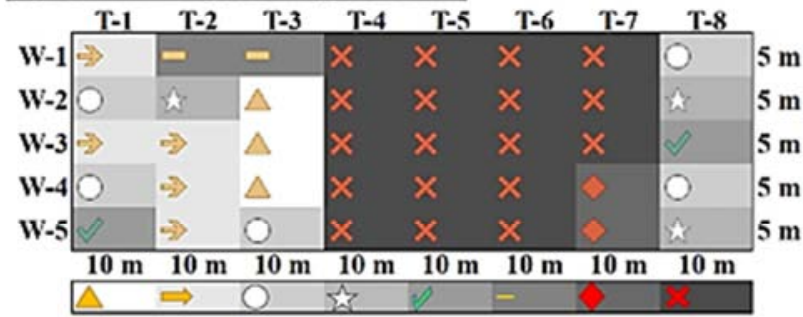

Penetration range (kPa)

\begin{tabular}{|l|l|l|l|l|l|l|l|l|}
\hline 1819 & 1845 & 1871 & 1897 & 1923 & 1949 & 1975 & From \\
\hline
\end{tabular} \begin{tabular}{|c|c|c|c|c|c|c|c|c|}
\hline 1844 & 1870 & 1896 & 1922 & 1948 & 1974 & 2000 & $>2000$ & To \\
\hline
\end{tabular}

Number of each color

\begin{tabular}{|c|c|c|c|c|c|c|c|c|}
\hline 3 & 5 & 5 & 3 & 2 & 2 & 2 & 18 & 40 \\
\hline
\end{tabular}

Area of each color $\left(\mathrm{m}^{2}\right)$ Total \begin{tabular}{|c|c|c|c|c|c|c|c|c|}
\hline 150 & 250 & 250 & 150 & 100 & 100 & 100 & 900 & 2000 \\
\hline
\end{tabular}

Preentage of each color $(\%)$ \begin{tabular}{|l|l|l|l|l|l|l|l|l|}
\hline 7.5 & $\mathbf{1 2 . 5}$ & $\mathbf{1 2 . 5}$ & $\mathbf{7 . 5}$ & $\mathbf{5}$ & $\mathbf{5}$ & $\mathbf{5}$ & $\mathbf{4 5}$ & $\mathbf{1 0 0}$ \\
\hline
\end{tabular} Table of data analysis for soil map

Figure 8. Distribution map of soil penetration resistance $(\mathrm{kPa})$ before tillage for three experimental pieces at soil layer 25 to $35 \mathrm{~cm}$ : a) no-tillage, b) uniform-depth tillage at $25 \mathrm{~cm}$ and c) uniform-depth tillage at $35 \mathrm{~cm}$. Where $T$ and $W$ are the symbol of rectangle area as shown in previously Figure 1. (a) Uniform-depth tillage at $45 \mathrm{~cm}$

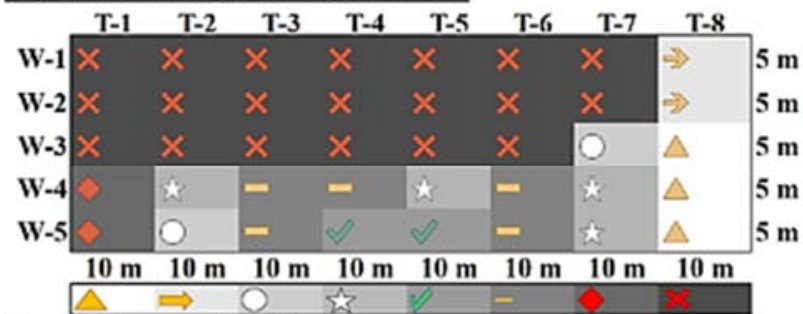

Penetration range $(\mathrm{kPa})$

\begin{tabular}{|l|l|l|l|l|l|l|l|l|}
\hline 1784 & 1815 & 1846 & 1877 & 1908 & 1939 & 1970 & \multirow{2}{*}{2000} & From \\
\hline 1814 & 1845 & 1876 & 1907 & 1938 & 1969 & 2000 & $\rightarrow 200$ & To \\
\hline
\end{tabular} \begin{tabular}{|l|l|l|l|l|l|l|l|l|}
\hline 1814 & 1845 & 1876 & 1907 & 1938 & 1969 & 2000 & $>2000$ & To $_{0}$ \\
\hline
\end{tabular}

Number of each color \begin{tabular}{|c|c|c|c|c|c|c|c|c|}
\hline 3 & 2 & 2 & 4 & 2 & 5 & 2 & 20 & 40 \\
\hline
\end{tabular}

Area of each color $\left(\mathrm{m}^{2}\right) \quad$ Total \begin{tabular}{|l|l|l|l|l|l|l|l|l|}
\hline 150 & 100 & 100 & 200 & 100 & 250 & 100 & 1000 & 2000 \\
\hline
\end{tabular} Prcentage of each color $(\%)$ \begin{tabular}{|c|c|c|c|c|c|c|c|c|}
\hline $\mathbf{7 . 5}$ & $\mathbf{5}$ & $\mathbf{5}$ & $\mathbf{1 0}$ & $\mathbf{5}$ & $\mathbf{1 2 . 5}$ & $\mathbf{5}$ & $\mathbf{5 0}$ & $\mathbf{1 0 0}$ \\
\hline
\end{tabular} Table of data analysis for soil map

(b) Variable-depth tillage

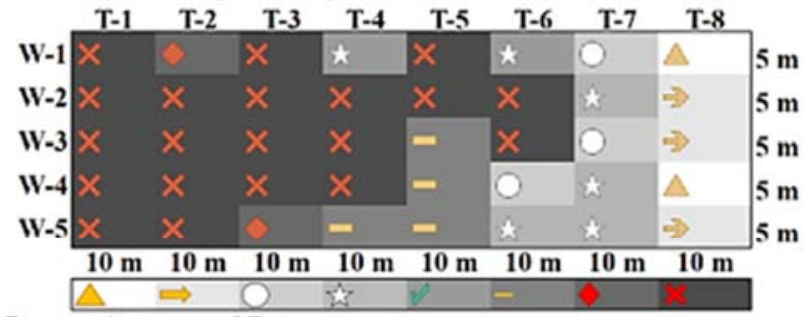

Penetration range ( $\mathrm{kPa})$

\begin{tabular}{|l|l|l|l|l|l|l|l|l|}
\hline 1805 & 1833 & 1861 & 1889 & 1917 & 1945 & 1973 & & From \\
\hline
\end{tabular}

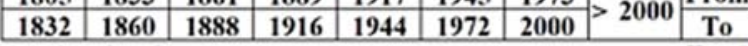
Number of each color

\begin{tabular}{|l|l|l|l|l|l|l|l|l|}
\hline 2 & 3 & 3 & 4 & 2 & 4 & 2 & 20 & 40 \\
\hline
\end{tabular}

Area of each color $\left(\mathrm{m}^{2}\right) \quad$ Total \begin{tabular}{|l|c|c|c|c|c|c|c|c|}
\hline 100 & 150 & 150 & 200 & 100 & 200 & 100 & 1000 & 2000 \\
\hline
\end{tabular}

Prcentage of each color (\%) Total \begin{tabular}{|c|c|c|c|c|c|c|c|c|}
\hline 5 & 7.5 & 7.5 & 10 & 5 & 10 & 5 & 50 & 100 \\
\hline
\end{tabular} Table of data analvsis for soil map

Figure 9. Distribution map of soil penetration resistance $(\mathrm{kPa})$ before tillage for two experimental pieces at soil layer $25-35 \mathrm{~cm}$ : a) uniform-depth tillage at $45 \mathrm{~cm}$ and b) variable-depth tillage. Where $T$ and $W$ are the symbol of rectangle area as shown in previously Figure 1.

(a) No-tillage

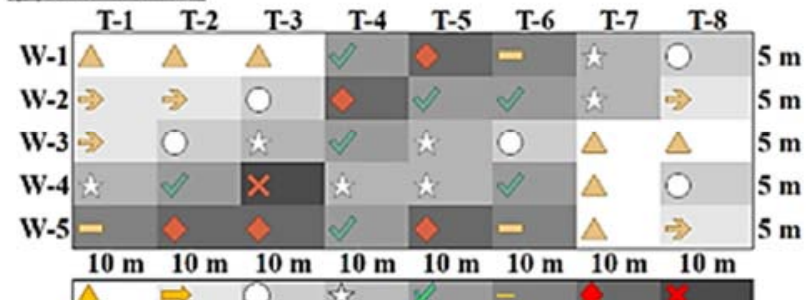

Penetration range $(\mathrm{kPa})$ \begin{tabular}{|l|l|l|l|l|l|l|l|l|}
\hline 1700 & 1736 & 1772 & 1808 & 1844 & 1880 & 1916 & & From \\
\hline 1735 & 1771 & 1807 & 1843 & 1879 & 1915 & 1951 & & To \\
\hline
\end{tabular} \begin{tabular}{|c|c|c|c|c|c|c|c|c|}
\hline 1735 & 1771 & 1807 & 1843 & 1879 & 1915 & 1951 & & \\
\cline { 1 - 6 } & & To \\
\hline
\end{tabular}

Number of each color \begin{tabular}{|c|c|c|c|c|c|c|c|c|}
\hline 7 & 5 & 5 & 7 & 7 & 3 & 5 & 1 & 40 \\
\hline
\end{tabular}

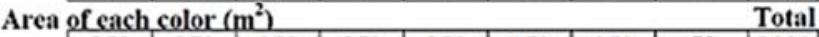
\begin{tabular}{|l|c|c|c|c|c|c|c|c|}
\hline 350 & 250 & 250 & 350 & 350 & 150 & 250 & 50 & 2000 \\
\hline
\end{tabular}

Prcentage of each color (\%) \begin{tabular}{|l|l|l|l|l|l|l|l|l|}
\hline 17.5 & 12.5 & 12.5 & 17.5 & 17.5 & 7.5 & 12.5 & 2.5 & 100 \\
\hline
\end{tabular} Table of data analysis for soil map 
(b) Uniform-depth tillage at $25 \mathrm{~cm}$

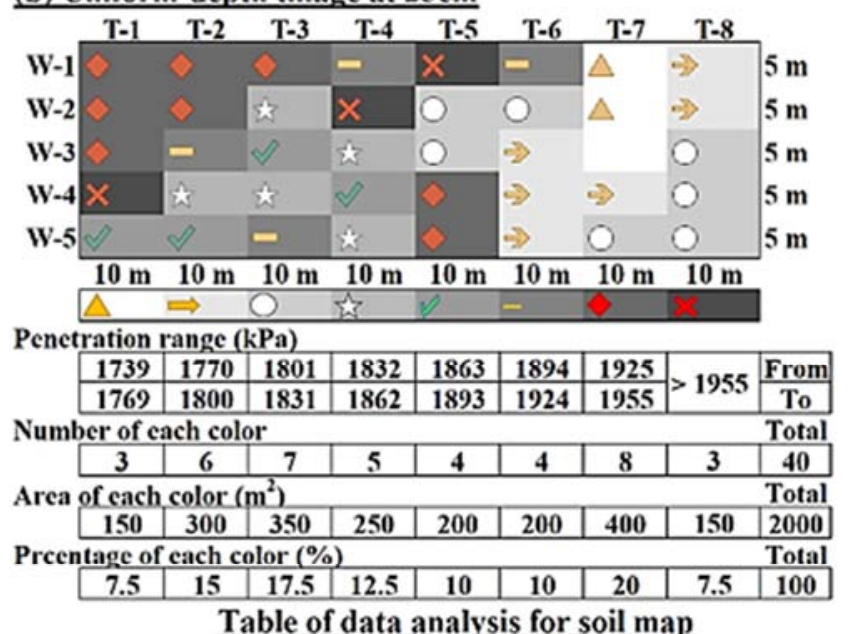

(c) Uniform-depth tillage at $35 \mathrm{~cm}$

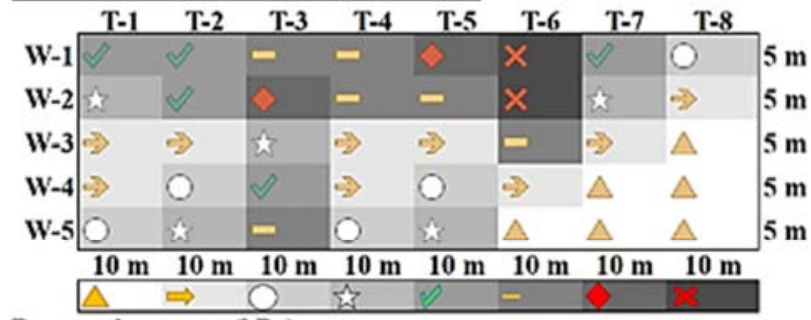

Penetration range $(\mathrm{kPa})$

\begin{tabular}{|c|c|c|c|c|c|c|c|c|}
\hline 1785 & 1811 & 1837 & 1863 & 1889 & 1915 & 1941 & & From \\
\hline 1810 & 1836 & 1862 & 1888 & 1914 & 1940 & 1966 & & To \\
\hline mber of & ch col & & & & & & & Total \\
\hline 6 & & $\frac{5}{\left.m^{2}\right)}$ & & 5 & 6 & & & \\
\hline 300 & 450 & 250 & 250 & 250 & 300 & 100 & 100 & 2000 \\
\hline - & $\frac{\text { ach ce }}{22.5}$ & $\frac{101 \%}{125}$ & & & & & 5 & \begin{tabular}{|l|} 
Total \\
100
\end{tabular} \\
\hline
\end{tabular}
Table of data analvsis for soil map

Figure 10. Distribution map of soil penetration resistance $(\mathrm{kPa})$ before tillage for three experimental pieces at soil layer 35 to $45 \mathrm{~cm}$ : a) no-tillage b) uniform-depth tillage at $25 \mathrm{~cm}$, c) uniform-depth tillage at $35 \mathrm{~cm}$., Where $T$ and $W$ are the symbol of rectangle area as shown in previously Figure 1.

\section{(a) Uniform-depth tillage at $45 \mathrm{~cm}$}

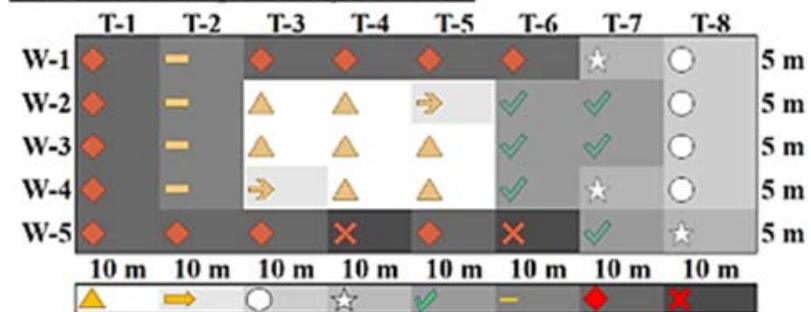

Penetration range (kPa)

\begin{tabular}{|c|c|c|c|c|c|c|c|c|c|}
\hline & 1703 & 1744 & 1785 & 1826 & 1867 & 1908 & 1949 & \multirow{2}{*}{$>1989$} & From \\
\hline & 1743 & 1784 & 1825 & 1866 & 1907 & 1948 & 1989 & & To \\
\hline \multicolumn{9}{|c|}{ Number of each color } & Total \\
\hline & 7 & 2 & 4 & 3 & 6 & 4 & 12 & 2 & 40 \\
\hline \multicolumn{9}{|c|}{ Area of each color $\left(\mathrm{m}^{2}\right)$} & Total \\
\hline & 350 & 100 & 200 & 150 & 300 & 200 & 600 & 100 & 2000 \\
\hline \multicolumn{9}{|c|}{ Prcentage of each color $(\%)$} & Total \\
\hline & 17.5 & 5 & 10 & 7.5 & 15 & 10 & 30 & 5 & 100 \\
\hline
\end{tabular}

Table of data analysis for soil map (b) Variable-depth tillage

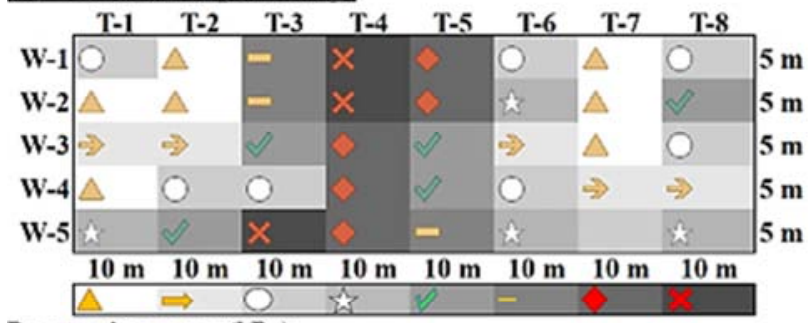

Penetration range $(\mathrm{kPa})$ \begin{tabular}{|l|l|l|l|l|l|l|l|l|}
\hline 1774 & 1805 & 1836 & 1867 & 1898 & 1929 & 1960 & & From \\
\hline 1804 & 1835 & 1866 & 1897 & 1928 & 1959 & 1990 & & ro \\
\hline
\end{tabular}

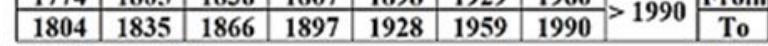

Number of each color $\quad$ Total \begin{tabular}{|l|l|l|l|l|l|l|l|l|}
\hline 7 & 5 & 8 & 4 & 5 & 3 & 5 & 3 & 40 \\
\hline
\end{tabular}

Area of each color $\left(\mathrm{m}^{2}\right)$ Total \begin{tabular}{|c|c|c|c|c|c|c|c|c|}
\hline 350 & 250 & 400 & 200 & 250 & 150 & 250 & 150 & 2000 \\
\hline
\end{tabular}

Preentage of each color $(\%)$ \begin{tabular}{|l|l|l|l|l|l|l|l|l|}
\hline 17.5 & 12.5 & 20 & 10 & 12.5 & 7.5 & 12.5 & 7.5 & 100 \\
\hline
\end{tabular}

Table of data analysis for soil map

Figure 11. Distribution map of soil penetration resistance $(\mathrm{kPa})$ before tillage for two experimental pieces at soil layer $35-45 \mathrm{~cm}$ : a) uniform-depth tillage at $45 \mathrm{~cm}$ and b) variable-depth tillage. Where $T$ and $W$ are the symbol of rectangle area as shown in previously Figure 1.

\subsection{Effect of Treatments on Fuel, Power Requirements, Specific Energy, Operating Cost, Sorghum Yield, Specific Cost of Yield and Actual Field Capacity}

Results as shown in Figure 12 showed that the highest values of fuel consumption rate $(1 / h)$, fuel consumption per unit area $(1 / \mathrm{ha})$, power requirements from fuel $(\mathrm{kW})$, specific energy $(\mathrm{kW} . \mathrm{h} / \mathrm{ha})$ and operating cost (LE/ha) were recorded at uniform-depth tillage $45 \mathrm{~cm}$ treatment. While the lowest values were achieved at no-tillage treatment. The results also showed that the decreasing percentage of fuel consumption rate $(1 / h)$, fuel consumption per unit area ( $1 / \mathrm{ha}$ ), power requirements from fuel $(\mathrm{kW})$, specific energy $(\mathrm{kW} . \mathrm{h} / \mathrm{ha})$ and operating cost (LE/ha) for variable-depth tillage treatment were $14.5 \%$, $21.2 \%, 14.5 \%, 21.2 \%$ and $8.7 \%$ respectively compared to uniform-depth tillage $25 \mathrm{~cm}$. The decreasing percentage of fuel consumption rate $(1 / h)$, fuel consumption per unit area $(\mathrm{L} / \mathrm{ha})$, power requirements from fuel $(\mathrm{kW})$, specific energy $(\mathrm{kW} . \mathrm{h} / \mathrm{ha})$ and operating cost $(\mathrm{LE} / \mathrm{ha})$ for variable-depth tillage treatment were $46.5 \%, 56.7 \%, 46.5 \%, 56.7 \%$ and $26.4 \%$ respectively compared to uniform-depth tillage $35 \mathrm{~cm}$. The decreasing percentage of fuel consumption rate $(\mathrm{l} / \mathrm{h})$, fuel consumption per unit area $(\mathrm{l} / \mathrm{ha})$, power requirements from fuel $(\mathrm{kW})$, specific energy (kW.h/ha) and operating cost (LE/ha) for variabledepth tillage treatment were $51.7 \%, 64.6 \%, 51.7 \%, 64.6 \%$ and $34.3 \%$ respectively compared to uniform-depth tillage $45 \mathrm{~cm}$. From results in Figure 13 no-tillage achieved the highest value of actual field capacity $(\mathrm{ha} / \mathrm{h})$ while the lowest value was at uniform-depth tillage $45 \mathrm{~cm}$. the results showed that increasing percentage of actual field capacity $(\mathrm{ha} / \mathrm{h})$ for variable-depth tillage were $8.5 \%, 21.4 \%$ and $34.2 \%$ compared to uniformdepth tillage $25 \mathrm{~cm}$, uniform-depth tillage $35 \mathrm{~cm}$ and uniformdepth tillage $45 \mathrm{~cm}$ respectively. The uniform-depth tillage $45 \mathrm{~cm}$ achieved the highest value of sorghum yield, fresh forage $(\mathrm{Mg} / \mathrm{ha})$ where the increasing percentage was $15.9 \%$ compared to variable-depth tillage. While the uniform-depth 
tillage $25 \mathrm{~cm}$ treatment achieved the highest value of specific cost of yield, (LE/Mg) where the increasing percentage was $68.3 \%$ compared to variable-depth tillage.

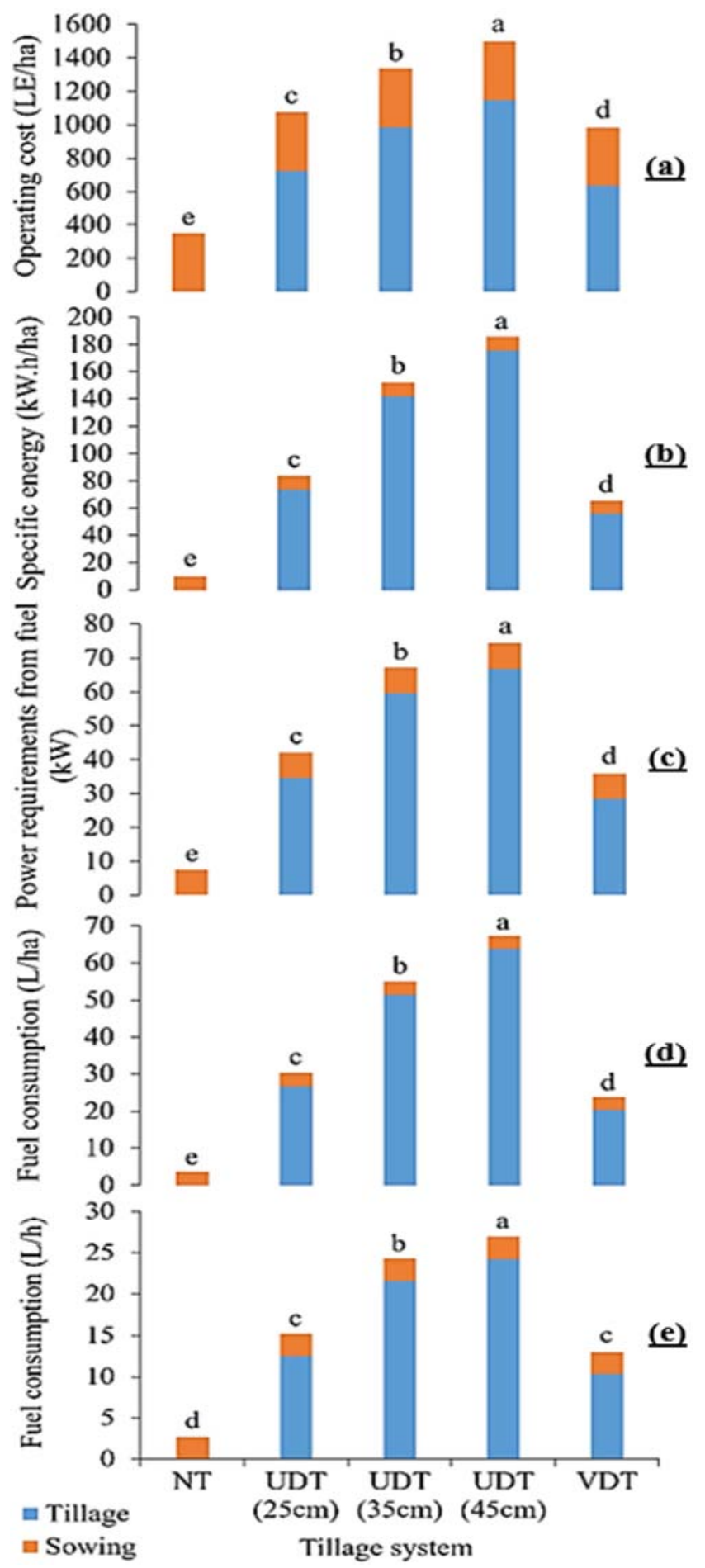

Figure 12. Effect of study treatments of no-tillage (NT), uniform-depth tillage (25cm) (UDT 25cm), uniform-depth tillage (35cm) (UDT, 35cm), uniform-depth tillage $(45 \mathrm{~cm})$ (UDT, $45 \mathrm{~cm})$ and variable-depth tillage (VDT) on a) operating cost (LE/ha), b) specific energy $(\mathrm{kW} . \mathrm{h} / \mathrm{ha})$, c) power requirements from fuel $(\mathrm{kW})$, d) fuel consumption $(\mathrm{l} / \mathrm{ha})$ and e) fuel consumption $(l / h)$. Values followed by different letters are significantly different at $p<0.05$ according to the LSD test. LSD for operating cost $=35.79$, specific energy $=10.35$, power requirements from fuel $=3.74$, fuel consumption per unit area $=2.75$ and fuel consumption $=2.49$.

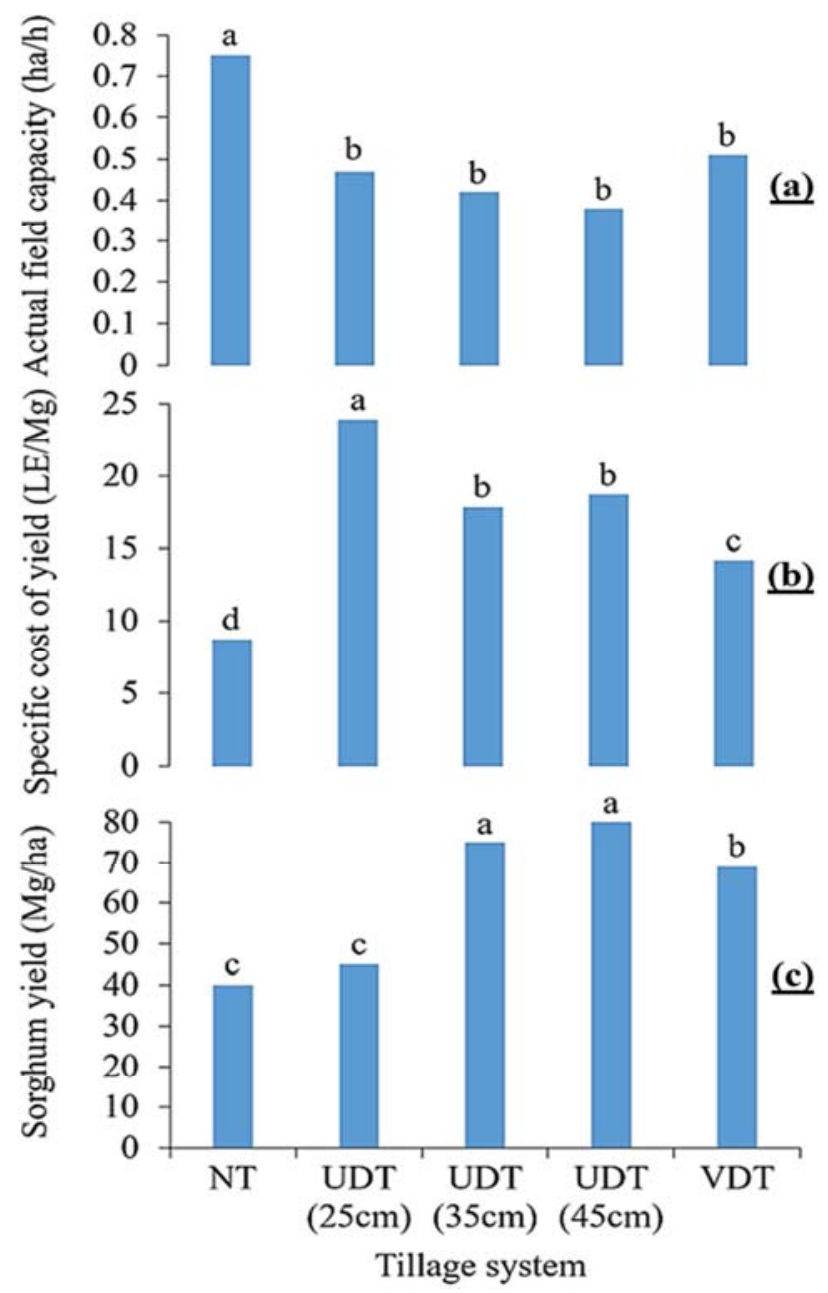

Figure 13. Effect of study treatments of no-tillage (NT), uniform-depth tillage $(25 \mathrm{~cm})$ (UDT $25 \mathrm{~cm})$, uniform-depth tillage $(35 \mathrm{~cm})$ (UDT, $35 \mathrm{~cm})$, uniform-depth tillage (45cm) (UDT, $45 \mathrm{~cm})$ and variable-depth tillage (VDT) on a) actual field capacity (ha/h), b) specific cost of yield (LE/Mg) and c) sorghum yield, fresh forage $(\mathrm{Mg} / \mathrm{ha}$ ). Values followed by different letters are significantly different at $p<0.05$ according to the LSD test. LSD for actual field capacity $=0.2$, specific cost of yield $=2.01$ and sorghum yield $=5.2$.

\subsection{Soil Penetration Resistance for Variable-Depth Tillage Area at Different Soil Depths 25, 35 and $45 \mathrm{~cm}$ Before and After Tillage}

The variable-depth tillage system was carried out by placing the cone tips of horizontal penetrometer at soil depths of $25 \mathrm{~cm}, 35 \mathrm{~cm}$ and $45 \mathrm{~cm}$, where the tillage in this system is only done in areas which soil penetration resistance higher than or equal to $2 \mathrm{MPa}$ (hardpan area) which showed in Figure (14 a, b and c) as the horizontal line extending from the value of soil penetration resistance $2000 \mathrm{kPa}$, so that the tillage will be done at a soil depth of $35 \mathrm{~cm}$ only because it is the layer containing the hardpan area, as specified before. Consequently, the layer under 35 $\mathrm{cm}$ depth will not be plowed because it does not contain hardpan areas. Therefore, the curve of soil penetration resistance values after tillage at $45 \mathrm{~cm}$ soil depth will approximately be similar to the values of soil penetration resistance before tillage for the same soil depth as shown in Figure 14 - a. Also, the curve of soil penetration resistance 
values after tillage at $25 \mathrm{~cm}$ soil depth, taking the same behavior as the curve of the soil penetration resistance values at $35 \mathrm{~cm}$ soil depth after tillage because the soil layer from zero to $35 \mathrm{~cm}$ is plowed all with the variable-depth tillage system which contains the layer $25 \mathrm{~cm}$. Thus, the curve of soil penetration resistance for the $25 \mathrm{~cm}$ and $35 \mathrm{~cm}$ layers after tillage take the same behavior as shown in Figure $14-\mathrm{b}$ and $\mathrm{c}$. In addition, Figure 14 showed that the control system succeeded in changing the tillage depth according to the values of soil penetration resistance.

\subsection{Soil Penetration Resistance for Study Treatments Before Tillage and After Harvesting of Sorghum Crop}

The results in Figure 15 showed that values of soil penetration resistance before applying the study treatments and after applying them until the period after harvesting of sorghum crop at different soil depths. The data showed that compaction layer was broken in treatments of uniform-depth tillage at tillage depths $35 \mathrm{~cm}$ and $45 \mathrm{~cm}$ and variable-depth tillage while the compaction layer remained in the treatments of no-tillage and uniform-depth tillage at tillage depth $25 \mathrm{~cm}$.

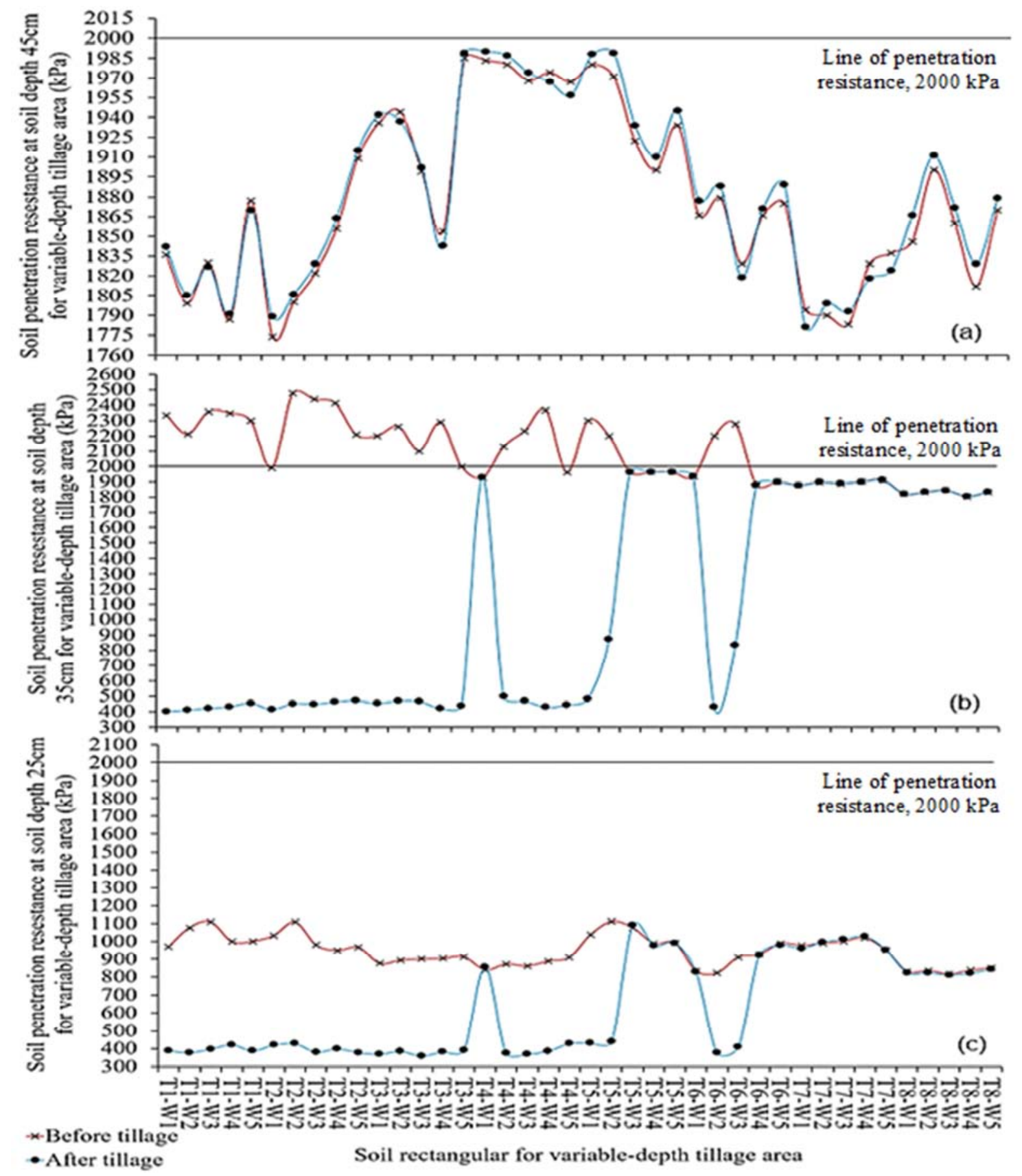

Figure 14. Soil penetration resistance for variable-depth tillage area at different soil depths $25 \mathrm{~cm}(\mathrm{c}), 35 \mathrm{~cm}(\mathrm{~b})$ and $45 \mathrm{~cm}$ (a) before and after tillage. Where $T-W$ is the symbol of rectangle area as shown in previously Figure 1. 


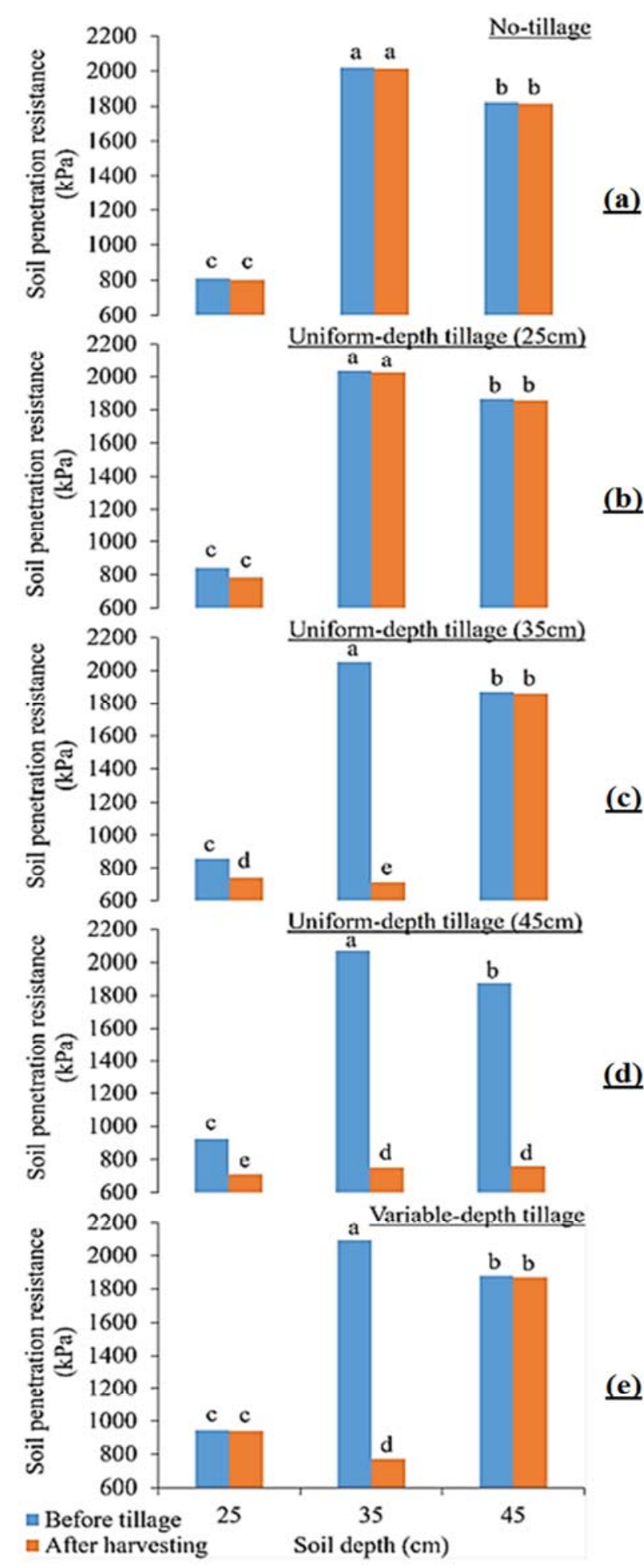

Figure 15. Soil penetration resistance for five study pieces: a) no-tillage, b) uniform-depth tillage $(25 \mathrm{~cm}), c)$ uniform-depth tillage $(35 \mathrm{~cm}), d)$ uniformdepth tillage $(45 \mathrm{~cm})$ and e) variable-depth tillage at different soil depths $(25 \mathrm{~cm}, 35 \mathrm{~cm}$ and $45 \mathrm{~cm})$ before tillage and after harvesting of sorghum crop. Values followed by different letters are significantly different at $p<0.05$ according to the LSD test. LSD for no-tillage $=16.95$, uniform-depth tillage $(25 \mathrm{~cm})=83.34$, uniform-depth tillage $(35 \mathrm{~cm})=2.29$, uniform-depth tillage $(45 \mathrm{~cm})=15.36$ and variable-depth tillage $=11.44$.

\section{Conclusion}

No-tillage as a conservation tillage system has advantages to save energy consumption about $79 \%$ compared to variable-depth tillage system but is not recommended if the soil is compacted since soil compaction restricts the root and crop development which, resulted in sorghum crop yield reduction about $42 \%$ compared to variable-depth tillage system. When conventional tillage system (uniform-depth tillage at $25 \mathrm{~cm}$ ) applied above soil layer compaction caused an increasing of energy consumption about $17 \%$ and decreasing of sorghum yield about $35 \%$ compared to variable-depth tillage system. However, when conventional tillage system applied at suitable tillage depth (uniform-depth tillage at $35 \mathrm{~cm}$ ) caused an increasing of energy and sorghum yield, about $87 \%$ and $8.7 \%$ respectively compared to variable-depth tillage system. However, when applied conventional tillage system (uniform-depth tillage at $45 \mathrm{~cm}$ ) below soil compaction layer caused an increasing of energy and sorghum yield, about $107 \%$ and $16 \%$ respectively compared to variable-depth tillage system. From the previous, conclude that the variable-depth tillage system avoided the disadvantages both of conventional and conservation tillage systems and achieved an increasing in crop productivity while saving energy consumed.

\section{References}

[1] CTIC 2010. Tillage type definitions. Conservation Technology Information Center. http://www.ctic.purdue.edu/media/pdf/TillageDefinitions.pdf.

[2] Keskin, S. G., Khalilian, A., Han, Y. J. and Dodd, R. B. 2011. Variable-depth tillage based on georeferenced soil compaction data in Coastal Plain Soils. International Journal of Applied Science and Technology, vol. 1, pp. 22-33.

[3] Gill, W. R. and Vanden Berg, G. E. 1968. Soil dynamics in tillage and traction. Agricultural Handbook no 316. U.S. Government Printing Office., Washington, D. C.

[4] Hill, R. P. and Mannering, J. V. 2009. Conservation tillage and water quality. WQ-20 1/95, Purdue University Cooperative Extension Service, West Lafayette, IN, USA.

[5] Domsch, H., Ehlert, D., Giebel, A., Witzke, K. and Boess, J. 2006. Evaluation of the soil penetration resistance along a transect to determine the loosening depth. Precision Agriculture, vol. 7, no. 5, pp. 309-326.

[6] Raper, R. L. 2003. Soil compaction management. In Encyclopedia of Agricultural, Food, and Biological Engineering, 902-905. D. Heldman, Ed. New York, N. Y.: Marcel Dekker.

[7] Craul, P. J. 1994. Soil compaction on heavily used sites. J. Arboriculture, 20 (2): 69-74.

[8] Raper, R. L., Reeves, D. W. and Burt, E. 1998. Using in-row subsoiling to minimize soil compaction caused by traffic. J. Cotton Sci. 2 (3): 130-135. 
[9] Al-Adawi, S. S., and Reeder, R. C. 1996. Compaction and sub-soiling effects on corn and soybean yields and soil physical properties. Trans. ASAE 39 (5): 1641-1649.

[10] Raper, R. L. 1999. Site-specific tillage for site-specific compaction: Is there a need? In the Proceedings of the 1999 International Conference of Dryland Conservation/Zone Tillage, Beijing, China.

[11] Fulton J. P., Wells, L. G., Shearer, S. A. and Barnhisel, R. I. 1996. Spatial variation of soil physical properties: a precursor to precision tillage. ASAE Paper No. 961012. St. Joseph, Michigan, USA.

[12] Palmer, A. L. and kruger, I. R. 1982. Comparative drafts of six tillage implements. In the Proceeding of the 1982 Conference on Agricultural Engineering, Armidale, NSW Australia, 22-24 August. Barton, Australia, pp: 163-167.

[13] Upadhyaya, S. K., Williams, T. H., Kemble, L. J. and Collins, N. E. 1984. Energy requirement for chiseling in coastal plain soils. Transactions of the ASAE, 36: 1267-1270 Service, pp: 316.

[14] Raper, R. L. and Reeves, D. W. 2004a. Reducing soil compaction with in-row subsoiling and controlled traffic. In: Proceedings of Session IV of the 2004 CIGR International Conference, October 11-14, 2004, Beijing, China.

[15] Kenan, K., Ozgoz, E. and Akbas, F. 2003. Assessment of spatial variability in penetration resistance as related to some soil physical properties of two fluvents in Turkey. Soil Till. Res. 76: 1-11.

[16] Naiqian, Z., Maohua, W. and Ning, W. 2000. Precision agriculture- a worldwide review. ICETS Session 6: Technology Innovation and Sustainable Agriculture: 112-122.

[17] Raper, R. L., Reeves, D. W., Burmeste C. H. and Schwab, E. B. 2000. Tillage depth, tillage timing and cover crop effects on Cotton yield, soil strength and tillage energy requirements. App. Eng. Agr. 16 (4): 379-385.

[18] Khalilian, A., Han, Y. J., Dodd, R. B., Sullivan, M. J. Gorucu, S. and Keskin, M. 2002. A control system for variable depth tillage. ASAE Paper No. 02-1209. St. Joseph, Mich.: ASAE.

[19] Ehlers, W., Popke, V., Hesse, F. and Bohm, W. 1983. Penetration resistance and root growth of oats in tilled and untilled loam soil. Soil Tillage Res. 3: 261-275.

[20] Taylor, H. M. and Gardner, H. R. 1963. Penetration of cotton seedling taproots as influenced by bulk density, moisture content and strength of soil. Soil Sci. 96: 153-545.
[21] Manor, G., and Clark, R. L. 2001. Development of an instrumented subsoiler to map soil hardpans and real-time control of subsoiler depth. ASAE Paper No. 011022. St. Joseph, Mich.: ASAE.

[22] Raper, R. L., Reeves, D. W., Shaw, J. N., van Santen E. and Mask, P. L. 2005a. Site-specific subsoiling benefits for cotton production. ASAE Paper No. 051025. St. Joseph, Mich.: ASABE.

[23] Abbaspour-Gilandeh, Y., Alimardani, R., Khalilian, A., Keyhani, A. R. and Sadati, S. H. 2006. Energy requirement of site-specific and conventional tillage as affected by tractor speed and soil parameters. Int. J. Agri. Biol. 8 (4): 499-503.

[24] Ess, D. and Morgan, M. 2003. The Precision Farming Guide for Agriculturists. Deere \& Company, Moline, Il, USA.

[25] Khalilian, A., Han, Y. J., Marshall, M. W., Gorucu, S., Abbaspour-Gilandeh, Y. and Kirk, K. R. 2014. Evaluation of the Clemson instrumented subsoiler shank in coastal plain soils, Computers and Electronics in Agriculture; 109 (2014) 46-51.

[26] Gorucu, S., Khalilian, A., Han, Y. J., Dodd, R. B. and Smith, B. R. 2006. An Algorithm to Determine the Optimum Tillage Depth from Soil Penetrometer Data in Coastal Plain Soils. Applied Engineering in Agriculture, 22 (5): 625-631.

[27] Kostic, M. M., Rakic, D. Z., Savin, L. D., Dedovic, N. M. and Simikic, M. D. 2016. "Application of an original soil tillage resistance sensor in spatial prediction of selected soil properties." Computers and Electronics in Agriculture 127 (2016): 615-624.

[28] Meselhy, A. A. 2020. Evaluation of locally made horizontal penetrometer to measure soil compaction under Egyptian conditions. Bioscience Research, 2020 volume 17 (3): 23312357.

[29] ASAE Standards 2004. ASAE S313.3 FEB04: Soil cone penetrometer. In: Hahn, R. H., M. A. Purschwitz and E. E. Rosentreter (Eds.). ASAE Standards 2004. ASAE. 2950 ASAE, St. Joseph, MI.

[30] Kepner, R. A., Bainer, R. and Barger, E. L. 1978. Principles of Farm Machinery. Ch 5, the AVI Publishing Company.

[31] El-Awady, M. N. 1978. Engineering of Tractor and Agricultural Machinery. Text Book, Fac. Of Ag. Ain Shams Univ., Cairo, Egypt.

[32] Hunt, D. and Welson, D. 2015. Farm power and machinery management $11^{\text {th }}$ Ed., Iowa State Univ., Ames, U.S.A. 